\title{
Effectiveness Of Forest Management As Affected By The Land Use Act In Onigambari Forest Reserve, Oluyole Local Government Area Ibadan, Nigeria.
}

\author{
Z .0. Yusuff \\ Department of Crop and Environmental Protection, \\ Ladoke Akintola University of Technology, Ogbomoso. Nigeria \\ L. O. Alamu \\ Department of Crop and Environmental Protection, \\ Ladoke Akintola University of Technology, Ogbomoso. Nigeria
}

\begin{abstract}
The growing demands for forest goods and services are putting serious pressure on the resource base, leading to over-exploitation and subsequent forest degradation. In Nigeria both natural and plantation forests could not meet 100 million $\mathrm{m}^{3}$ of the 180 million $\mathrm{m}^{3}$ wood demand in 2000 . At present, one of the most challenging problems facing the country is the production of sufficient food and fiber to meet the needs of the ever-increasing population (Peters, 2005). This study examined the effectiveness of forest management in Onigambari forest reserve, Oluyole Local Government Area Ibadan, Nigeria. The study employed a simple random sampling technique to select 43 forest farmers randomly. Descriptive tools such as frequency distribution, percentage, mean, ranking and Pearson product moment correlation (PPMC) was used as inferential statistical tool to determine the forest management performance in the study area while Student T-test was used to test for the significance difference of the relationship between the forest managers and locals. Result showed that mean age of respondents is 39.65 years. A tittle above Forty Eight percent of the respondents were females while $51.16 \%$ of the respondents were males, A tittle above Eighteen percent of the respondents were single while $81.40 \%$ of the respondents were married. The result of Student t- test revealed that the mean of age is higher than the mean total effects indicating improved performance of age on the total effects in the study area. The $p$ value $(0.0000)$ is smaller than the chosen alpha value $(0.05)$ which has the $t$-value of 6.840. The result further revealed that deforestation is now becoming history as a result of land use policy on forest management and it has the highest weighted mean score of 2.86 and ranked as the first, followed by the demand of local industries can partially be met second $(W M S=2.74)$. The result on Pearson product moment correlation revealed that some of the selected factors such as poor participation of people involved in forestry $\left(\mathrm{r}=\mathbf{1 . 0 0 0}^{* *} ; \mathrm{p}<=\mathbf{0 . 0 1}\right)$, use of inexperience foresters $(\mathrm{r}=$ $0.262^{*} ; p<0.05$ ) and poor conflicts management between local farmers and foresters $\left(r=0.387^{*} ; p<0.05\right)$ respectively exhibited a significant relationship between forest managers and locals/indigenous people. The study recommended that there should be increase in communication among all stakeholders to ensure the harmonization of all interests towards a better use of forest resources, also effective continuous public enlightenment is essential to secure the interest and participation of farmers with an effective mechanism for good governance, equitable benefit sharing, and lastly, conflict resolution mechanism should be established.
\end{abstract}

Keywords: Forest management, Land Use Act, Foresters, Local farmers, Forest resources. 


\section{INTRODUCTION}

The world's forest area has been declining for centuries but the process has accelerated to alarming proportions in the last half of the twentieth century (CFAN, 2003). In 2005, the estimated forest area for Africa was 635 million ha; net annual forest loss was about 4 million ha for the period 2000-2005, which amounts to almost 55\% of the global reduction in forest area (FAO, 2007). A significant share of net forest loss was reported from countries with the greatest extent of forest, with Nigeria accounting for most of the loss in West Africa (FA0, 2007). Adedoyin (2001) put forest depletion in Nigeria at about 3.5\% per annum, which translates to the loss of 350 000-400 000 ha per annum. (FAO, 2015) reported that, Nigeria with an annual loss of 410000 ha between 2010 and 2015 is one of the countries with the greatest annual forest reduction. Tropical rainforests provide a vast array of products, which are relevant to the livelihood of the inhabitants of the tropical environment (Faleyimu, 2000). Around $80 \%$ of the population in developing countries uses non-wood forest products from tropical forests to meet nutrition and health needs.( FA0,1999).

In Nigeria, forests provide a wide range of wood and non-wood products as well as social and environmental services. However, the growing demands for these forest goods and services are putting serious pressure on the resource base, leading to over-exploitation and subsequent forest degradation (Onuoha, 1999; Oyebo, 2002). In Nigeria both natural and plantation forests could not meet 100 million $\mathrm{m}^{3}$ of the 180 million $\mathrm{m}^{3}$ wood demand in 2000 (Aruofor, 2000). At present, one of the most challenging problems facing the country is the production of sufficient food and fiber to meet the needs of the ever-increasing population (Peters, 2005). This outlook was earlier presented by (Akinsanmi, 1998) who observed existing pressure to destroy the forests through logging, agriculture, urbanization and indiscriminate deforestation for different purposes. In most developing countries, agriculture, forestry and urban development land uses are unplanned, resulting in improper land use. Integrating land uses with emphasis on sustainable economic development and ecological balance is imperative. Integration of agriculture and forestry results in various agroforestry practices incorporating various interand intra sectoral components in the system. However, in as much as the two interests must be integrated, the fact remains that forests cannot be substituted (Jarvis, 1991). Unlike Scandinavian countries, forest management in Nigeria is mainly a government concern. Earlier attempts made by the Colonial Administration to manage the Nigerian forest reserves using the tropical shelterwood system (TSS) and other enrichment planting recorded little success (Nwoboshi, 1982). The need to meet the increasing demand for wood products and the accompanying slow growth rate of most forest tree species shifted emphasis from natural to artificial regeneration (Oguntala, 1978; Evans, 1992). Two methods of artificial regeneration practiced in Oyo State, south-western Nigeria, to develop plantations were the direct planting system and the taungya system (Oyo State Forestry Department, 2008).

The management of most forest reserves fails to address the important functions of forest to host and protect sites with high cultural, spiritual or recreational values, and benefits to agriculture and rural livelihoods. Though there is usually provision in the constitution of forest reserves which stipulates admission of rights of local inhabitants to access routes and certain minor forest produce, the legal, policy and institutional arrangements necessary to support the above, including participatory decision making, governance, law enforcement, monitoring and assessment of progress, are not in place. As observed by Adeyoju (2005) the communities around most forest reserves have become hostile to forestry related activities and would hardly stop anything harmful to the forest estate. Records also show that most forest reservation processes were not completed especially in the South-South zone of Nigeria where adequate compensation were not paid and therefore, the original owners have since returned to claim their lands. Examples are Biseni and Orashi forest reserves where state forestry 
department needs to take permission from the natives before carrying out any activity in the forest (Larinde, 2010).

The big question is how can forest management be effectively carried out to enhance forest enrichment? This paper therefore seeks to:

determine the effects of land use act on forest management and identify the relationship between the forest managers and locals/indigenous people in the area.

\section{METHODOLOGY}

The population of this study was $43 \%$ of the forest farmers in the study area. The farmers included those that have experience in forest management and other activities related to land use management. The data for the study was collected through questionnaire for the learned and interview schedule for the not so learned. The study employed a simple random sampling technique. Primary data was exclusively used for this study. The forest farmers were randomly selected and interviewed. The dependent variable was the perceived effects of land use act on forest management; while Independent variables were personal characteristics of the respondents.

The data for this study was analyzed with both descriptive tools such as frequency distribution, percentage, mean and ranking, while Pearson product moment correlation (PPMC) was used as inferential statistical tool to make an inference on the collected data. T-test was also used to test for the significance difference between foresters and local farmers in terms of the knowledge gap created by management effectiveness.

\section{RESULTS AND DISCUSSION}

The result of the descriptive statistics as shown in Table 1 revealed the mean age is 39.65 years. This implies that majority of the respondents are in their active age. The distribution of the respondents based on their sex revealed that $48.84 \%$ of the respondents are female while $51.16 \%$ of the respondents were male. This implies that majority of the respondents in the study area are males. The result also shows that $18.60 \%$ of the respondents are single while $81.40 \%$ of the respondents were married. This implies that majority of the respondents in the study area were married. The result of education levels indicated that $2.33 \%$ of the respondents attended primary school, $2.33 \%$ of the respondents attended secondary school while $95.34 \%$ of the respondents attended tertiary school. This implies that most of the respondents are educated. The result further shows that $9.30 \%$ of the respondents are into farming, $83.72 \%$ of the respondents are civil servant while $6.98 \%$ of the respondents engaged in others occupations. This implies that the civil servants in the forestry have adequate awareness and knowledge of utilizing forest resources. The result shown in Table 1 described the years spent in school by the respondents in the study area. $67.44 \%$ of the respondents spent between $1-6$ years, $13.95 \%$ spent $7-12$ years and $18.60 \%$ of the respondents spent above 12 years in school. This result shows that most of the respondents spent at least 6 years in school. Finally, the result of years of farming experience revealed that $4.65 \%$ of the respondents have less or equal to one year of experience, $51.16 \%$ have $2-10$ years of experience, $39.53 \%$ of the respondents have $11-20$ years of experience and $4.65 \%$ of the respondents have above 20 years of experience in their primary occupation respectively. This implies that most of the respondents have at least 10 years of experience in primary occupation. 
Table 1: Distribution of the Respondent's by Age

\begin{tabular}{|c|c|c|c|}
\hline Age (years) & Frequency & Percentage & Cumulative percentage \\
\hline$<=25$ & 1 & 2.33 & 2.33 \\
\hline $26-35$ & 10 & 23.26 & 25.58 \\
\hline $36-45$ & 25 & 58.14 & 83.72 \\
\hline $46-55$ & 5 & 11.63 & 95.35 \\
\hline$>55$ & 2 & 4.65 & 100.00 \\
\hline \multicolumn{4}{|l|}{ Sex } \\
\hline Female & 21 & 48.84 & 48.84 \\
\hline Male & 22 & 51.16 & 100.00 \\
\hline \multicolumn{4}{|c|}{ Marital Status } \\
\hline Unmarried & 8 & 18.60 & 18.60 \\
\hline Married & 35 & 81.40 & 100.00 \\
\hline \multicolumn{4}{|c|}{ Education Level } \\
\hline Primary & 1 & 2.33 & 2.33 \\
\hline Secondary & 1 & 2.33 & 4.66 \\
\hline Tertiary & 41 & 95.34 & 100.00 \\
\hline \multicolumn{4}{|c|}{ Primary Occupation } \\
\hline Farming & 4 & 9.30 & 9.30 \\
\hline Civil servant & 36 & 83.72 & 93.02 \\
\hline Others & 3 & 6.98 & 100.00 \\
\hline \multicolumn{4}{|c|}{ Years spent in School } \\
\hline $1-6$ & 29 & 67.44 & 67.44 \\
\hline $7-12$ & 6 & 13.95 & 81.40 \\
\hline$>12$ & 8 & 18.60 & 100.00 \\
\hline \multicolumn{4}{|l|}{ Experience } \\
\hline$<=1$ & 2 & 4.65 & 4.65 \\
\hline $2-10$ & 22 & 51.16 & 55.81 \\
\hline $11-20$ & 17 & 39.53 & 95.35 \\
\hline$>20$ & 2 & 4.65 & 100.00 \\
\hline
\end{tabular}

Source: Field survey, 2019.

\section{EFFECT OF LAND USE ACT ON FOREST MANAGEMENT}

The student t-test was used to analyze the effect of land use act on forest management in Onigambari Forest Reserve, Oyo state. The paired t-test and two sample t-test with equal variance are the types of t-test used. Table 2 revealed the result obtained from the mean value of the total respondents and the mean value of their age (paired t- test) and table 3 revealed the result obtained from the mean value of the total respondents and the mean of their sex. Two different groups (male and female) are compared with the total population of the respondents (the two sample t- test with equal variance). According to Table 2 the mean of age is higher than the mean total effects indicating improved performance of age on the total effects in the study area. The p value (0.0000) is smaller than the chosen alpha value (0.05) which has the $t$-value of 6.840. This implies that there is a significant mean difference between age and the total effects on forest management. The higher the age the higher the total effects on forest management

Table 2: Paired t-test to determine the Effect of Age on Forest Management

\begin{tabular}{lcccccc}
\hline Variable & Observation & Mean & $\begin{array}{c}\text { Standard } \\
\text { Error }\end{array}$ & $\begin{array}{c}\text { Standard } \\
\text { Deviation }\end{array}$ & (95\% Confidence Interval) \\
\hline Age & 43 & 39.651 & 1.189 & 7.798 & 37.251 & 42.051 \\
Total & 43 & 29.814 & 0.889 & 5.828 & 28.020 & 31.608 \\
Difference & 43 & 9.837 & 1.438 & 9.431 & 6.935 & 12.740 \\
\hline
\end{tabular}

Source: Field survey, 2019.

Mean $($ difference $)=$ mean $($ age - total $) \quad t=6.840$ 


\section{GENDER EFFECT OF LAND USE ACT ON FOREST MANAGEMENT.}

Student t-test was used to analyze the effect of land use act on forest management in Onigambari Forest Reserve, Oyo state. Two different groups (male and female) were compared with the total population of the respondents (the two sample t- test with equal variance). According to Table 3 there is no significant difference in the means. Therefore, the null hypothesis $\left(\mathrm{H}_{0}\right)$ is accepted which means that the gender has no effect on forest management.

Table 3: Two - sample t-test with equal variances to determine the effects of sex on forest management

\begin{tabular}{lcccccc}
\hline Group & Observation & Mean & $\begin{array}{c}\text { Standard } \\
\text { Error }\end{array}$ & $\begin{array}{c}\text { Standard } \\
\text { Deviation }\end{array}$ & (95\% Confidence Interval) \\
\hline Female & 21 & 28.762 & 1.345 & 6.164 & 25.956 & 31.568 \\
Male & 22 & 30.818 & 1.160 & 5.440 & 28.407 & 33.230 \\
Combined & 43 & 29.814 & 0.889 & 5.828 & 28.020 & 31.608 \\
Difference & & -2.056 & 1.771 & & -5.632 & 1.520 \\
\hline
\end{tabular}

Source: Field survey, 2019.

Difference $=$ mean (female) - mean (male) $\quad t=-1.161$

\section{DISTRIBUTION OF RESPONDENTS BASED ON PERCEIVED EFFECT OF LAND USE ACT ON FOREST MANAGEMENT}

For this objective, five level likert scale of strongly disagree (SA); agree (A); undecided (U); disagree (D); and strongly disagree (SD) respectively. Weighted mean score was calculated which was used to determine the ranking order of perceptional statement regarding the relationship between the forest managers and locals/ indigenous people.

The result shows in Table 4 revealed that deforestation is now becoming history as a result of land use policy on forest management and it has the highest weighted mean score of 2.86 and ranked as the $1^{\text {st }}$, followed by the demand of local industries can partially be met $2^{\text {nd }}$ (WMS= 2.74). The statement that the role of land use act in relation to forest management has led to dispute and conflicts is ranked $3^{\text {rd }}$ (WMS $=2.60$ ), land use act has greatly affected the availability of non-timber forest products (NTFPs) (WMS $=2.56,4^{\text {th }}$ ), the land use decree has denied the right of the migrant farmers/forest occupant whose means of livelihood hinge on availability of land for cultivation thereby leading to discouragement in the afforestation (WMS $=2.49,5^{\text {th }}$ ) were ranked in similar order, while the statement that afforestation is encouraged due to the land use act on forest management has the least weighted mean score of 2.19 and was ranked $12^{\text {th }}$.

The result above implies that land use act has not greatly impacted much to forest management. This may be due to variation in the level of management in different forest reserves. 
Table 4: Distribution of Respondents based the Effects of Land Use Act on Forest Management

\section{STATEMENT}

Frequency (percentage)

Level of agreement

Afforestation is encouraged due

to the land use act on forest

management

Deforestation is now becoming

history in this area as a result of

land use policy on forest

management

With the current population of

forest in terms of its availability, the demand of local industries can be partially met which can be attributed to policy on land use on forest management

Land use has encouraged many

forest species and animal

extinctions

Land use act policy has lead to

desert encroachment which is

invariably discouraging

afforestation

The foresters play major role in

the enforcement of land use

policy and pre-requisite to forest

management

The role of land use act in relation to forest management has lead to dispute and conflicts in this area Land use act has greatly affected the availability of non-timber forest products (NTFPs) in this area

The land use act has lead to displacement of many farmers in the forest area

Due to land use decree farmers are not only excluded from the ownership of their land and control of forest resources, they are also disempowered The exclusion of stakeholders (such as local community dwellers, hunters, farmers, timber contractor and other non-timber resource users) in the administration of forest directly or indirectly has led to poor forest governance and the consequent crises in forest reserves

The land use decree has denied the right of the migrant farmers / forest occupant whose means of livelihood hinge on availability of land for cultivation thereby leading to discouragement in the afforestation

\begin{tabular}{|c|c|c|c|c|c|c|}
\hline SA & A & $\mathrm{U}$ & D & SD & WMS & RANK \\
\hline $14(32.56)$ & $16(37.21)$ & $6(13.95)$ & $5(11.63)$ & $2(4.65)$ & 2.19 & $12^{\text {th }}$ \\
\hline $8(18.60)$ & $9(20.93)$ & $10(23.26)$ & $13(30.23)$ & $3(6.98)$ & 2.86 & $1^{\text {st }}$ \\
\hline $4(9.30)$ & $17(39.53)$ & $9(20.93)$ & $12(27.91)$ & $1(2.33)$ & 2.74 & $2^{\text {nd }}$ \\
\hline $10(23.26)$ & $16(37.21)$ & $6(13.95)$ & $9(20.93)$ & $2(4.65)$ & 2.47 & $6^{\text {th }}$ \\
\hline $8(18.60)$ & $19(44.19)$ & $5(11.63)$ & $10(23.26)$ & $1(2.33)$ & 2.47 & $6^{\text {th }}$ \\
\hline $9(20.93)$ & $23(53.49)$ & $5(11.63)$ & $2(4.65)$ & $4(9.30)$ & 2.28 & $10^{\text {th }}$ \\
\hline $8(18.60)$ & $16(37.21)$ & $7(16.28)$ & $9(20.93)$ & $3(6.98)$ & 2.60 & $3^{\text {rd }}$ \\
\hline $10(23.26)$ & $12(27.91)$ & $10(23.26)$ & $9(20.93)$ & $2(4.65)$ & 2.56 & $4^{\text {th }}$ \\
\hline $7(16.28)$ & 21(48.84) & $6(13.95)$ & $6(13.95)$ & $3(6.98)$ & 2.47 & $6^{\text {th }}$ \\
\hline $10(23.26)$ & $29(44.19)$ & $3(6.98)$ & $8(18.60)$ & $3(6.98)$ & 2.42 & $9^{\text {th }}$ \\
\hline $11(25.58)$ & $19(44.19$ & $5(11.63)$ & $6(13.95)$ & $2(4.65)$ & 2.28 & $10^{\text {th }}$ \\
\hline $12(27.91)$ & $13(30.23)$ & $6(13.95)$ & $9(20.93)$ & $3(6.98)$ & 2.49 & $5^{\text {th }}$ \\
\hline
\end{tabular}

Source: Field survey, 2019. 


\section{RELATIONSHIP BETWEEN THE FOREST MANAGERS AND LOCALS/ INDIGENOUS PEOPLE}

Pearson product moment correlation was used. Test of the significant relationship between the factors that affecting forest management were used as the variables. According to the result of the analysis in Table 5, some of the selected factors such as poor participation of people involved in forestry $\left(\mathrm{r}=1.000^{* *} ; \mathrm{p}<=0.01\right)$, use of inexperience foresters $\left(\mathrm{r}=0.262^{*} ; \mathrm{p}<0.05\right)$ and poor conflicts management between local farmers and foresters ( $\left.r=0.387^{*} ; \mathrm{p}<0.05\right)$ respectively exhibited the significance relationship between forest managers and locals/indigenous people. Therefore, the null hypothesis $\left(\mathrm{H}_{0}\right)$ is rejected; hence alternative hypothesis $\left(\mathrm{H}_{\mathrm{a}}\right)$ is accepted. This means there is significant relationship between the forest management and locals/indigenous people. The dependence of the locals on forest resources makes it imperative for them to relate with management activities and the forest managers.

Table 5: Test of significant relationship between the forest managers and locals/ indigenous people

\begin{tabular}{|c|c|c|c|c|}
\hline Factors affecting forest management & Correlation coefficient & r-value & Decision & Remark \\
\hline $\begin{array}{l}\text { Poor participation of people involved in } \\
\text { forestry }\end{array}$ & $1.000^{* *}$ & 1 & S & Reject $\mathrm{H}_{0}$ \\
\hline $\begin{array}{l}\text { Sanction decision and importance of } \\
\text { forest office }\end{array}$ & -0.435 & 0.006 & NS & Accept $\mathrm{H}_{0}$ \\
\hline $\begin{array}{l}\text { Encouragement of discrimination and } \\
\text { social inequalities in rural area }\end{array}$ & -0.166 & 0.319 & NS & Accept $\mathrm{H}_{0}$ \\
\hline Use of inexperience foresters & $0.262^{*}$ & 0.112 & $\mathrm{~S}$ & Reject $\mathrm{H}_{0}$ \\
\hline $\begin{array}{l}\text { Poor relationship between forest } \\
\text { managers and local farmers }\end{array}$ & $-0.142 S$ & 0.396 & NS & Accept $\mathrm{H}_{0}$ \\
\hline $\begin{array}{l}\text { Inadequate incentives on the part of } \\
\text { foresters }\end{array}$ & 0.093 & 0.577 & NS & Accept $\mathrm{H}_{0}$ \\
\hline $\begin{array}{l}\text { Poor conflicts management between the } \\
\text { local farmers and foresters }\end{array}$ & $0.387^{*}$ & 0.016 & $\mathrm{~S}$ & Reject $\mathrm{H}_{0}$ \\
\hline
\end{tabular}

\section{Source: Field survey, 2019.}

**: Correlation is significant at the 0.01 level (2- tailed)

*: Correlation is significant at the 0.05 level (2- tailed)

S: Significant

NS: Non significant

Ho: Null hypothesis

\section{CONCLUSION AND RECOMMENDATION}

From this study it can be concluded on findings that for the Land Use Act to achieve the reforms for which it was hoped, concerted and honest efforts need to be made to ensure its thorough and impartial implementation. The socio-economics characteristics of the respondents has effects on the land use act has on forest management. Other results also showed a significant relationship among all the variables included in the study and forest management. Land use act has not helped in the encouragement of discrimination and social inequalities in rural area. There is also a poor relationship between forest managers and local farmers.

\section{References}

Adedoyin O.S. 2001. Formulation implementation of National Forestry Programmes in Nigeria.

Adeyoju, S.K (2001). Forestry for national development: A critique of the Nigerian situation, pp. 55-67. In: Popoola, L, Abu, J.E and Oni, P.I. (Eds.) Forestry and National Development. Proceedings of 27th Annual conference of Forestry Association of FCT, Abuja, Nigeria. 
Adeyoju, S.K. (2005). Institutional Arrangements in Support of Sustainable Forest Management in Nigeria. pp: 590-598. In: Popoola, L; Abu, J.E. and Oni P.I. (Eds.) Sustainable Forest Management in Nigeria: Lesson and prospects. Proceeding of the 30th Annual Conference of the Forestry Association of Nigeria held in Kaduna, Kaduna, State, Nigeria. 07th to 11th November, 2005.

Aiyeloja, A.A and Faleyimu, O.I (2011). Management of Forest Reserves in South-west Nigeria, pp 48- 68. In: A. A Aiyeloja and H.M. Ijeomah (Eds.). Book of Readings in Forestry, Wildlife Management and Fisheries. Topbase Nig. Ltd., Lagos, in conjunction with Green Canopy Consultants, Port Harcourt, Nigeria

Azeez I.O, Ikponmwonba O.S, Popoola L, Amusa T.0. 2010: Land use activities among forest environments' dwellers in Edo State, Nigeria: implications for livelihood and sustainable forest management. International Journal of Social Forestry 3: 164-187.

Faleyimu 0.I. 2000. Bio-prospecting: investigating the indigenous uses of forest plant seeds and seed oil potentials of Monodora myristica (Gaertn.) Dunal in Ogun State, Nigeria. BForWMgt thesis, University of Agriculture, Abeokuta, Nigeria.

FAO (Food and Agriculture Organization of the United Nations). 1999. Non-wood forest products. Forestry Information Notes. Rome: FAO.

FAO, 2000. 'The challenges of sustainable forestry development in Africa', 21st FAO Regional Conference for Africa, 21-25 February 2000, Yaoundé, Cameroon. Rome: FAO. pp 21-25.

Food and Agriculture Organization (2001). Criteria and indicators of sustainable forest management of all types of forests and implications for certification and trade. Secretariat Note. 15th session of the Committee on Forestry, 12-16 March 2001.

FAO, 2007. State of the world's forests 2007. Rome: FAO. Rome.

Larinde, S.L. (2010). Restoration of oil spill mangrove vegetation in Rivers and Bayelsa State, Nigeria. Report Submitted to Ministry of Niger-Delta Affairs, Abuja. Unpublished

Oguntala, A.B. 1978. Natural and artificial regeneration in Nigeria. Paper presented at the 8th Annual Conference of the Forestry Association of Nigeria, Ilorin, Nigeria, 13-16 December 1978.

Onuoha, C.M. 1999. Environmental impact of forest depletion and suggested sustainable management strategies in Nigeria. In: Obiaga PC, Abu JE, Popoola L, Ujor G (eds), Conservation of Nigeria's natural resources and the threatened environment: proceedings of the 26th Annual Conference of the Forestry Association of Nigeria in Maiduguri, Borno State, Nigeria, 19-23 April 1999. Ibadan: Forestry Association of Nigeria. pp 50 - 61.

Oyebo, M.A. 2002. Prospects for private forestry in Nigeria. In: Popoola L (ed.), Forest, people and environment: proceedings of a national workshop in Benin City, Edo State, Nigeria, 5-6 September 2002. Ibadan: Forestry Department, Edo State; FAN-Consult. pp 88-102.

Oyo State Forestry. 2008. Annual report. XXXXX: Department of Forestry, Ministry of Agriculture and Natural Resources.

Rhuks, T. Ako, "Nigeria's Land Use Act: An Anti-Thesis to Environmental Justice" Journal of African Law, 53, 2 (2009), 289-304 (C) School of Oriental and African Studies, United Kingdom.

Udofia, S.I. 2005. Conservation of biodiversity through appropriate sustainable forest management strategies. In: Popoola L, Mfon P, Oni PI (eds), Sustainable forest management in Nigeria - lessons and prospects: proceedings of the 30th Annual Conference of the Forestry Association of Nigeria, Kaduna, Nigeria, 7-11 November 2005. Ibadan: Forestry Association of Nigeria. pp 92-104. 